NOTES ON NEIV ENGLAND ACRIDIDAE.-III. OEDIPODINAE.- I.

BY ALBERT 1 . MORSE, WELIESLEY, MASS.

This group of locusts has been ahly monographed at a comparatively recent date by Saussure in his Prodromus and its scquel.* A liey to the genera is given in each, the latter being the more complete.

He divicles the entire group into three legions - Oedipodites, Thrincites, Eremobites - according to the presence or absence of the apical spur on the externat margin of the hind tibiae, and the position of the ocelli. All of our species belong to the first group, lacking the spine and having the ocelli placed near the eyes.

This group he divides, with one exception, into two series according to the width of the space between the lobes of the metasterumm. To the first series, having this space relatively narrow, belong Arphia, Chortophaga, Encoptolophus, and three genera not represented in New England; to the other series, with the space relatively wicle, belong all the remaining genera, about 60 in number, which are classified chiefly with reference to the form of the head and pronotum and texture of the tegmina. For further details, and for an explanation of the characters used in systematic treatment, nomenclature of vention, etc., the student should consult this admirable work.

\footnotetext{
- Prodromus Oedipodioram Insectorum ex ordine Or. thopteronm-Stern. soc, phys. et dhist. nat. d. Genève, xxviii, No.9 (1954); Additamenta ad Prodromum Oedipodiorum, ibid, xxx, No, I (1SS8). In French and Latin.
}

In the following paper I have treated the genera in the order of the systematic arrangement as given by Saussure, but in the key to species I have made use of many cluaracters of little or no systematic importance, preferring to use those which will enable the novice to determine specimens with the most ease and accuracy. The techuical terms found in the key will be readily comprehended, in case of doubt, by a glance at the plate.

To the Oedipodinate belong all of the New England locusts having brightcolored wings, a fact which, taken in connection with their moderate or large size, causes them to be rather conspicuous objects in flight. Not all of our species are thus decorated. but by far the larger number - twelve out of fifteen - the remaining three having them either pellucid or fiantly clouded. It is worthy of notice in this connection that the latter occur in greater abundance of inclividuais than their more conspicuous relatives, and that they frequent fields with an abundance of grass rather than places where the herbage is sparse, which seem more attractive to many of the others They are also much less shy and active than the bright-winged ones, which are the wariest and most difficult to capture of all our locusts.

In the brightly-colored wings the color may be mainly black, yellow or 
red, rellow tints predominating. It is in no sense protective and bears no relation to the environment, but is probalbly of value in the mating of the sexes. It may vary much in the same species, but the sexes are similu. This variation is partly due, no doubt. to age ; for newly matured individuals of a yellow winged species have the disk very pale, even dull white in color. In some species (e. g., Psinidia fenestralis) individuals show all shades of color from dull white through yellow and orange to vermilion red. This rariation may be found in the same locality or the orange and red examples may be lacking. In Hippiscus tuberculatus, whose wings are normally red, yellowwinged ex:mples are very rare.

Prof. Bruner has sought to connect this difference of wing-color with the relative humidity of diflerent localities, stating that the red coloration seemed to be most prevalent in moist regions (Science. 1S93, p. 13.3). This, however, has been questioned (ibid., p. 245). In New England I have found red-winged examples of $P_{S}$. fenestralis most common in the warmest parts of the district and suspect that the greater intensity of coloration is due in part to higher temperature. This is apparently trut also of Arphia santhoptera which is entirely yellow-winged here but in the Central States is frequently orange-ivinged. The yellow-winged examples of $H$. tuberculatus above referred to are probably to be regarded as cases of reversion, most species of the genus being yellow-winged.

The Oedipodinae are noticeable not only from their size and gaily colored wings but quite as much from the rattling noise which the males of many species produce in flight. The female also, in some cases, makes it in less clegree. Stridulation is produced not only at this time, however, but alsis when at rest. as in the Tryailinae, by rubbing the hind thighs against the wing-covers, the intercalary vein of which is in most cases toothed or roughened. 'This subject 1 have treated more fully in a recent p.rper (Journ. N. I. ent. soc., iv, I6-20, Mar. ISg6).

Owing, douhtless, to the conspicuous character of the locusts of this group) the majority of our species were first described at an early date from material received fiom this country by European entomologists. Consequently I have been unable to examine the types, and have used the current names (based upon Scudler's determinations) except in the genus Spharagemon, in which I have followed my recent Revision (Psjolie, iS95, Oct.).

The works cited under bibliography, unless otherwise noted, are the same ats in Parts $I$ and II* with the aldition of Saussure's Prodromus.

Owing to their alertness most of the locusts of this group can be secured only by marking down ( $i$.e., taking note of the exact spot where they alight), approaching carefully, and capturing them by a rapid sweep of the net while they are on the ground or

\footnotetext{
* These are in brief. Bentenmüller,-Orth. N. Y.; Comstock,-Introd, Fernald,-Orth. N. E.; Morse,-List : Scudder,-Materials; Smith,-Orth. Me., Orth Conn.; Thomas,-Synop. Acrid. N. A.
} 
when they rise. Ch. viridifasciata. $E$. so, didus, and $C$. pellucida are exceptions to this and may generally be readily obtained by the usual metiod of sweeping, only an occasional specimen of the other species being secured in this mamner. The larger part of the specimens in my collection, about 2000 in number, have been taken personally, and I have met in the field all of the species treated with the exception of Hippisius rugosus.
Correlated with their active aerial habits is the uniformly well-developed condition of the flight-organs; not a solitary example with abortive wings is known to me of the New England species of this subfamily,--al peculiarity in which it presents a marked contrast to the others. Consequently, as being of but relatively slight interest I have omitted from the measurements here given the extent of the tegmina bejond the hind femora.

\section{DESCRIPTION OF THE BOT-FLY OF THE COTTON-TAIL RABBIT IN NEW MEXICO, CUTEREBRA LEPUSCULI N. SP.}

BY C. H. 'TYLER TOWNSEND. LAS CRUCES, X. M.

Upon examination of Mr. E. E. Ansten's two papers on Cuterebra, in the May and August, 1 S95, numbers of the Amnals and Magazine of Natural History, and a re-examination of my material from cottontails and jack-rabbits, two points become rery evident. One is that the species, which I have so far referred to $C$. fontinella Clark, is a new species; and the other is that the bots taken from jack-rablsits, which I referred to Dermatolia, belong to the new genus Bogeria of Austen. For my previons papers, the reader is referred to Psyche, vol 6, pp. 29S-300; and Insect Life, vol. 5, pp. 317-320. My certainty in determining my specimens as $C$. fontinclla rested on the general agreement of Clark's description, the similar host habit, the not too greatly removed locality of Clark's species, and the fact that but little reliance can be placed in many cases on the measurements of the old authors when given in lines. But since Mr. Austen, with the necessary material and plates at his command, has determined C. fontinella Clark beyond doubt to be a much smaller and very different species from my own, it becomes evident that my conclusion was wrong. The following description is that drawn from my two bred specimens described in Insect Life. These specimens are now in the collection of the University of Kansas.

\section{Cuterebra lepusculi $n$. sp.}

Cut. fontinella Towns. Ins. Life, v. 319 (nec. Clark and Austen.)

\&. Length of body, $20.5 \mathrm{~mm}$. to $21 \mathrm{~mm}$.; width of abdomen, $9 \mathrm{~mm}$. $1095 \mathrm{~mm}$; width of thorax, $9 \mathrm{~mm}$. or a little more; width of head, $8 \mathrm{~mm}$ to $8.25 \mathrm{~mm}$. ; length of wing, $16 \mathrm{~mm}$. to $16.25 \mathrm{~mm}$. Fiont about seven-sixteenths widh of head at vertex, grayishblack, scantily gratyish-hairy, with two 

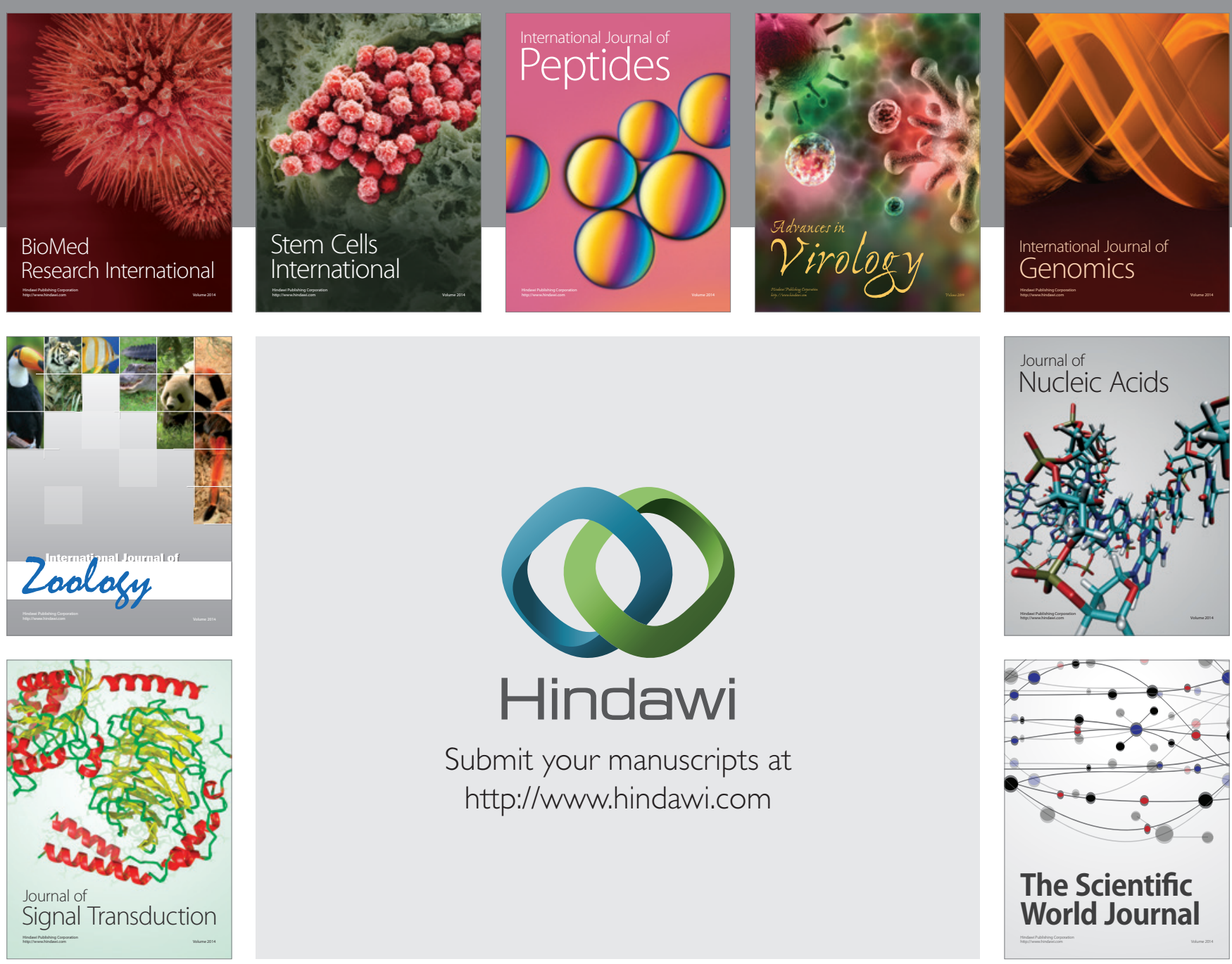

Submit your manuscripts at

http://www.hindawi.com
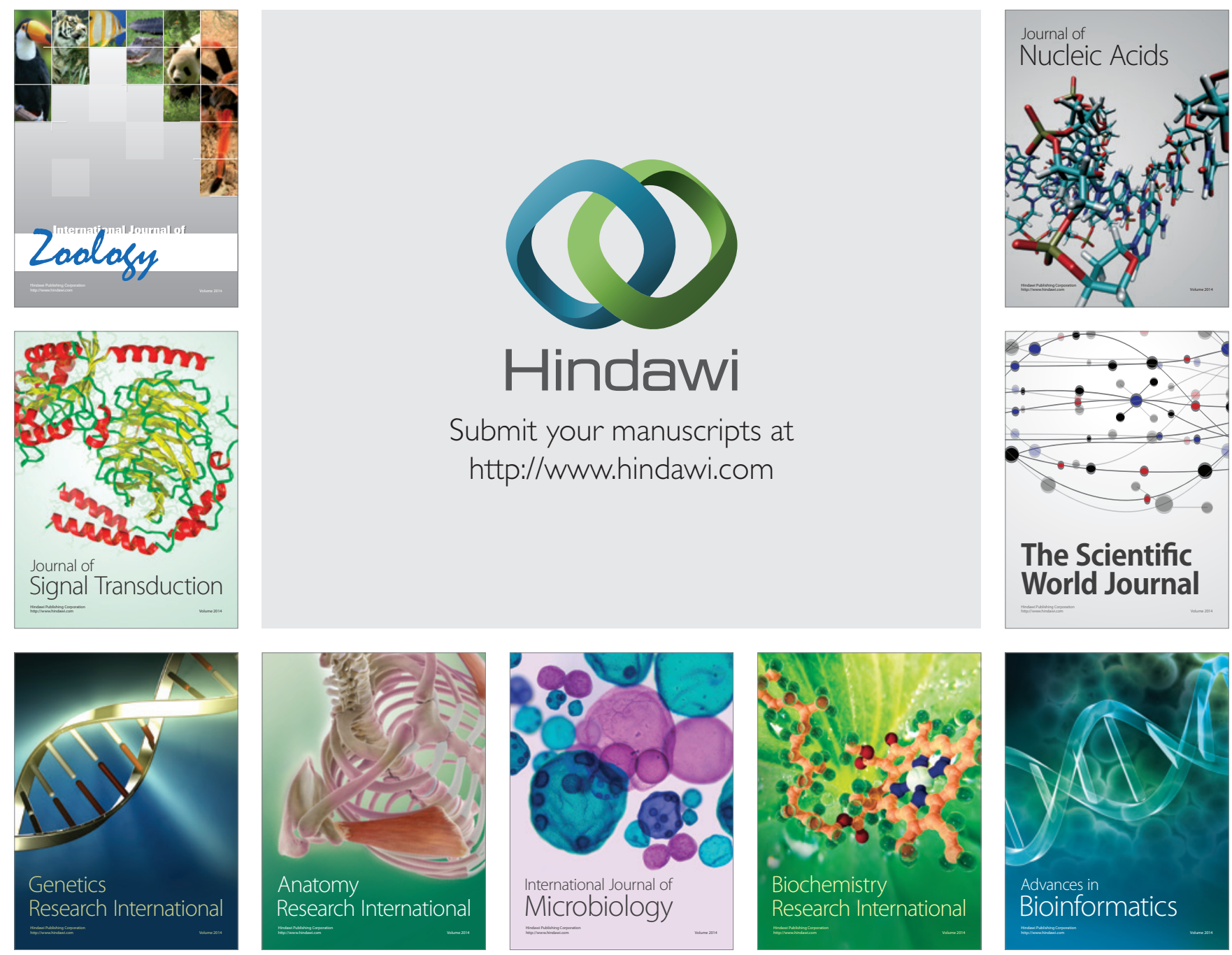

The Scientific World Journal
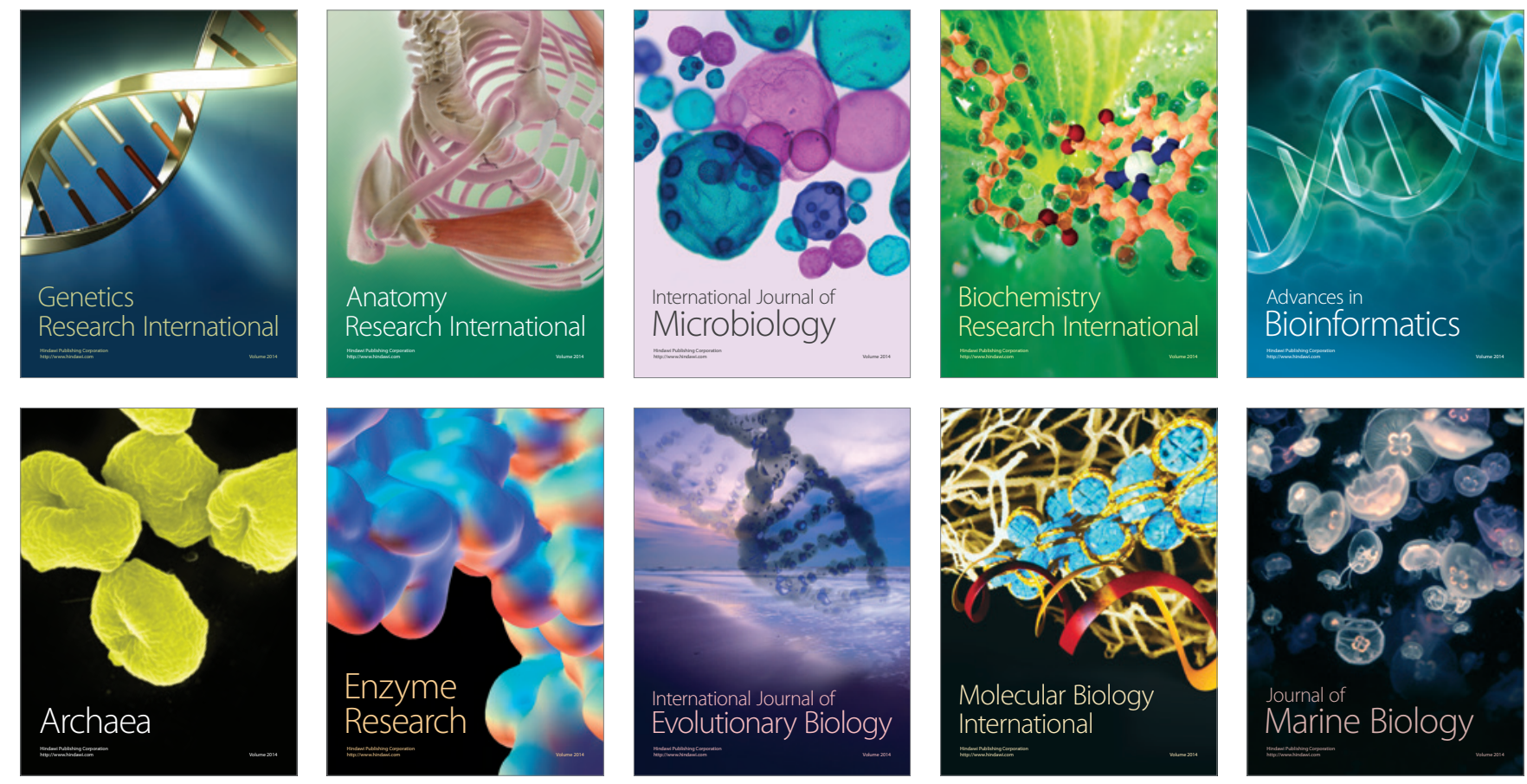